\title{
Analysis of Arc Stability in MIG Brazing of 304L Stainless Steel Using Solid and Flux-Cored Wire
}

Pavol Sejč, Rastislav Kubíček

Faculty of Mechanical Engineering, Slovak University of Technology in Bratislava, Pionierska 15, 83102 Bratislava, Slovak Republic, E-mail: pavol.sejc@stuba.sk

At the present time, consumables assortment intended for utilization of MIG brazing process enables its application possibilities also for the joining of high-alloyed austenitic steels. In that case, the substitution of arc welding processes (such as MIG/MAG, or TIG) by the brazing process makes it possible to limit the weldability issue related to the crystallization of weld metal (hot cracking) and to the deformations (induced by excessive amount of heat input to the joint). Additional technological benefits may be offered by an application of flux-cored wires, which have been utilizing successfully within arc welding processes.

Submitted paper is aimed to verify differences in the character and behaviour of arc metal transfer and in the stability of arc during MIG brazing of austenitic stainless steel by selected types of solid and flux-cored wire electrodes.

Keywords: Arc-Brazing, Brazing of 304L, Flux-Cored wire, Arc Stability

\section{References}

[1] SEJČ, P., BIELAK, R., ŠVEC, P., ROŠKO, M. (2006). Computer simulation of heat affected zone during MIG brazing of zinc-coated steel sheets. Kovové materiály. Metallic materials, Roč. 44, č. 4, s. 225 - 234.

[2] SEJČ, P., BELANOVÁ, J., KUBíČEK R. (2011). Utilization of plasma arc at the metallurgical joining of zinc coated plates to aluminium. Kovové materiály. Metallic materials, roč. 49, č. 6, s. 437 - 449.

[3] VIŇÁŠ, J., KAŠČÁK, L., DRAGANOVSKÁ, D. (2012). Evaluation of corrosion resistance of MIG brazed steel sheets. Acta Metallurgica Slovaca, roč. 18, č. 4, s. $162-171$.

[4] HERMAN, P. (2002). Bronzové trubičkové dráty pro MIG pájení. Zváranie - Svařování, roč. 51, č. 9 - 10, s. 213.

[5] CARY, H. B., HELZER, S. C. (2005). Modern Welding Technology. Pearson Prentice Hall, New Jersey, s. 715.

[6] STN EN ISO 24373 (2008). Welding consumables - Solid wire and rods for fusion welding of copper and copper alloys - Clasification.

[7] CHOVET, C., GUIHEAUX, S. (2006). Possibilities offered by MIG and TIG brazing of galvanized ultra high strength steels for automotive applications. La metalurgia italiana, č. 7 - 8, s. 47 - 54.

[8] http://www.lucasmilhaupt.com/en-US/products/fillermetals/hightemperaturealloys/6/

[9] VARGA, V., MIČIAN, M., PALLO, P., MEŠKO, J., ZÁHORANSKÝ, R. (2009). Electric Arc Instability at GMAW Welding Induced by Implication Defocts in Welding Joints, Journal of Machine Manufacturing, roč. 49, s. 61 - 63.

[10]ONDREJČEK, P. (2003). Zváranie ocelí v ochrane plynov, Eterna Press s. r. o., Bratislava, s. 202. 